2020-06-06

\title{
Where to draw the line: the difference between a fan and a pirate in Japan
}

Schroff, Simone

http://hdl.handle.net/10026.1/13750

10.1080/10286632.2019.1604694

International Journal of Cultural Policy

Informa UK Limited

All content in PEARL is protected by copyright law. Author manuscripts are made available in accordance with publisher policies. Please cite only the published version using the details provided on the item record or document. In the absence of an open licence (e.g. Creative Commons), permissions for further reuse of content should be sought from the publisher or author. 
Where to draw the line: the difference between a fan and a pirate in Japan

By Simone Schroff ${ }^{1}$

\section{Abstract}

This article examines the gap between the public discourse favoured by right holders and politicians for strict copyright enforcement and industry practice where infringement is tolerated and sometimes even facilitated by the same right holders. Drawing on the Japanese contents sector surrounding Manga, Anime and video games, the interaction between strict copyright provisions, positive and negative market impact and broader considerations such as reputation and pay-offs are contextualised. It is demonstrated that right holders do not see infringing behaviour as such as a cause of action nor does it dominate how right holders want users to interact with their products. Instead, it is the wider context which determines if copyright will be enforced or not. Based on an analysis of copyright law, stakeholder interviews and observations at industry and stakeholder events, this paper clarifies where right holders draw the line between a pirate and a fan, especially the limited influence copyright law has in practice.

\section{Keywords}

Copyright, Japanese contents sector, fan-created works, piracy, market harm

\footnotetext{
${ }^{1}$ Lecturer in Law at the University of Plymouth, Visiting Researcher at Waseda University and Associated Researcher at the Institute for Information Law at the University of Amsterdam. This research has been supported by the Canon Foundation in Europe. I would like to thank the reviewers and Lisa DeBlasio for their insightful comments. All errors remain my own.
} 


\section{Introduction}

Copyright protection is fundamental to making cultural products economically viable. In legal theory and the political discourse, only high levels of protection can ensure that right holders get the economic benefit they deserve. ${ }^{2}$ In this context, the rise of digital technology has inspired a flurry of legal reforms to limit user behaviours that are considered prejudicial to copyright holders' interests. However, while copyright holders actively seek these legal revisions, their business strategy only partially relies on them. In fact, some infringing behaviour is tolerated and sometimes even promoted: copyright is enforced ${ }^{3}$ selectively on purpose.

Selective copyright enforcement poses risks to the system as whole. First, large scale non- enforcement of existing law has the potential to make its enforcement in future close to impossible. The legitimacy of legal provisions declines in the eyes of the user if they are not enforced. Secondly, selective enforcement leads to uncertainty in the market with potentially detrimental impact on innovation. It enables the right holder to privilege one type of user over another although both may be carrying out the same type of behaviour from a legal point of view. Selectively strong enforcement against potential competitors in particular can have a chilling effect on new business models and guide users towards established, preferred distribution channels. Selective enforcement can therefore affect how markets work, the balance between users and right holders as well as the legitimacy of copyright as whole.

This article addresses this contradiction between the political and legal discourse calling for strong protection on one side and the industry practice on the other, drawing on the example of Japan where the gap is especially pronounced. Using Japan as a case study

\footnotetext{
2 This underlying narrative can be found in most copyright instruments at the regional and global level, such as EU's Information Society Directive (EU, 2001, recital 4 and 9) and Enforcement Directive (EU, 2004, recital 10 and 21), the TRIPs Agreement and the ill-fated ACTA Agreement.

${ }^{3}$ The term enforcement is used broadly here and includes both the exercise of rights by individual (private) right holders and the enforcement of rights by the government.
} 
allows for more widely applicable insights. First, the contents sector as we know it today has developed under a copyright law which is firmly rooted in Western concepts (especially German ones). Secondly, Japan has a long-established, highly integrated and internationally operating cultural sector whose output is attractive to both the domestic and foreign audiences. The Japanese government identified especially the existing success of Japanese comics (Manga), cartoons (Anime) and video games as the spearheads for a broader appreciation of Japanese culture in the Cool Japan Strategy (Cool Japan Strategy, 2018; Mehra, 2002, 163). Thirdly, Japan has also been at the forefront of international copyright policy, developing bilateral (Courmandis, 2009) and multilateral strategies for higher levels of protection (Braithwaite, 2001).

This article adds to the current state of knowledge on copyright infringement by moving away from the purely theoretical realm. It is based on research carried out in Tokyo (Japan) between 2017 and 2018, combining desk research with a series of unstructured interviews. Overall, there were 31 interviews (covering 43 participants) with academics, legal practitioners, industry representatives/ right holders and fan artists. The research also included observations at events selected for their high attendance numbers, such as the Comiket (December 2017) and several Anime and Manga conventions hosted at the Tokyo Big Sight. In addition, the author attended industry podium discussions and seminars (most of them VIPO organised) and conducted observations in areas where fan culture is central, such as Harajuku and Akihabara. ${ }^{4}$ Through the interviews and observations, this article

\footnotetext{
${ }^{4}$ The interviews touched on sensitive topics, including infringement by the interviewees (relevant for the fan interviews), de-facto deviation from company policy (right holders) and unofficial assessments of enforcement patterns (by legal advisors). As a result, all interviews declined to be recorded and indeed selected to remain anonymous. Meeting this requirement is especially pressing in the Japanese context because all interviewees agreed to take part in the research after the author was introduced them by an associate or friend, often personally vouching for the author. I will therefore only reference interviews by stakeholder category but not individual numbers as conclusions could be drawn on the identity of the individual.
} 
contextualises existing theoretical and anecdotal accounts, focusing on what those directly involved consider important.

In the first section, the role of copyright in the creative industries, its recent developments as well as the Japanese case study will be introduced. Then, the discussion moves to the different kinds of infringing behaviour that are prevalent in Japan in the digital context. The aim is to clarify what kind of unauthorised uses exist and their status under copyright law. The third section will then analyse right holder responses to copyright infringement, identifying the factors they take into consideration when they decide on how and when to exercise their copyrights and when to tolerate or even support the infringer.

\section{Copyright and the Creative Sector: The Background Story}

Content reaches the audience in different forms based on what is called a windowing strategy. In this strategy, different versions of the same product are tailored to the specific audience in a temporal and spatial manner to get as close as possible to what each audience is willing to pay (Landes and Posner, 2003). ${ }^{5}$ For example, a feature film is commonly first released in cinemas, followed by DVDs, streaming and broadcasting. At each step, the individual right holder earns less per individual customer, but more people can access the product. Similarly, customers are divided according to territory: DVDs will be cheaper in a lower income country than they are higher income one. To implement this strategy, copyright is essential.

Copyright law provides the right holder with the necessary control over their content. In its most narrow conceptualisation, copyright law protects the original expression of an

\footnotetext{
${ }^{5}$ For a discussion of how Manga, Anime and video games are linked in a windowing strategy, see Schroff (2019)
} 
author (Berne Convention, article 2). Subject to a minimum originality requirement, ${ }^{6}$ the expression can take a variety of different forms such as literary works, comics, computer software and games as well films and music. These works can be monetised since copyright law gives the right holder control over how the work is shared. In Japan, the different kinds of uses are individually listed as economic rights and in effect directly comparable in scope with US or European ones. They include the reproduction, distribution, public performance, public transmission and rental of works (Japanese Copyright Act, chapter 2 section 3). In addition, the law provides for a series of sanctions if these exclusive rights are infringed, ranging from civil law remedies such as fines to criminal ones including prison sentences (Japanese Copyright Act, chapters 7 and 8).

Like all copyright laws around the world, the exclusive rights are not absolute. Instead, there are exemptions for particular uses or situations (Japanese Copyright Act, chapter 2 section 5). As Kato (2013, 227-229) emphasises, these share a number of common characteristics. First, exemptions are limited by the purpose. These are narrowly defined and are either in the public interest, such as education, or the individual cost of enforcement is too high, for example in the case of private copying. However, they all contain a remuneration requirement where a centralised system collects revenues to be distributed to the right holders. Secondly, the use has to be essentially non- commercial. Under Japanese law, this means that no fees are charged to participate in the activity and that no profit is generated. Infringing behaviour are activities which fall under the exclusive rights but are not exempt under the law. In theory, all infringing behaviour is illegal and therefore subject to enforcement.

\footnotetext{
${ }^{6}$ Originality is reflected in the choices the author makes such as the words he chose to express an idea (Komada et al, 2016, 23-24).
} 


\section{Digital Technology and Copyright Law}

Digital technology and the rise of the internet have created new ways in which individuals can copy, edit and re-use copyright material. As a result, the balance between users and right holders has shifted as many new uses started to affect established business models (Arai, 2005; Intellectual Property Strategy Headquarters, 2017), triggering a series of reforms to address them. ${ }^{7}$ In particular, right holders have actively lobbied for amendments to the law to ensure they can control how their works are used and distributed in the digital environments (Yamada, 2012; 2016). Policy- makers in turn have proven responsive to these efforts. This trend is visible across the world as copyright has increasingly become a trade concern and features in multilateral and bilateral trade agreements. ${ }^{8}$

In line with the international trends, the Japanese government has also actively promoted the interests of right holders. Since the government adopted the Intellectual Property Strategy (Arai, 2005), industry representatives lobbied aggressively for copyright reform and were successful despite significant public discontent (Yamada, 2012; 2016). The Cool Japan Strategy added copyright as a key component for business support abroad for the sectors under examination here: Manga, Anime and video games (Cabinet Office, 2018). In other words, the economic importance of the creative content and its protection via the law are core to the Japanese copyright approach, both domestically and abroad.

Despite the legal reforms, most users will infringe copyright in one way or another. This ranges from making backup copies of CDs to sharing images on social media. ${ }^{9}$ Most notably, right holders today focus their enforcement efforts not on individual, small scale

\footnotetext{
${ }^{7}$ A detailed history of copyright reform is beyond the scope of this article. See Goldstein (2010), Lessig (2004) and Yamada (2012).

${ }^{8}$ For an early version, see Breathwaite and Drahos (2000). Recent examples includes TTIP, TPP and bileratal agreements between the EU, Japan and the US with third countries.

${ }^{9}$ What exactly constitutes copyright infringement depends on national legislation.
} 
infringers but on gateways and large- scale offenders. ${ }^{10}$ These are commonly referred as pirates: copyright infringers who cause significant damage and benefit financially from their actions. ${ }^{11}$ While this shift in enforcement can also be observed in the US and EU, Japan stands out in this respect because Japanese right holders have been exceptionally successful in getting stringent sanctions and spent significant political capital on achieving their aims. At the same time, there is very little record of them actually using the harshest sanctions, including the criminal sanctions in place for the illegal film and music downloads which cost them so much political capital (Yamada, 2016, 59-91).

\section{Infringing behaviour surrounding Manga, Anime and video games}

Before the right holders' responses can be analysed, it is key to understand the piracy landscape around Manga, Anime and video games and how these relate to copyright law. This is the focus of this section.

The first type of piracy is the illegal uploading and downloading of copyright works, either as whole episodes or as snippets such as scenes from an Anime or Manga as well as recorded gameplay. The key difference between these two is where they are made available: there are specialist sites and torrents for full episodes. For extracts, the main outlets are content- sharing platforms such as NikoNiko and YouTube.

There is no doubt about the illegality of these activities. Under Japanese copyright law, making a work available online is subject to the exclusive right to transmit a work to the public (Japanese Copyright Act, article 23 and 2(1)(vii-ii)) as long as a substantial part of the

\footnotetext{
${ }^{10}$ This was not least driven by the huge public backlash and reputational damage that targeting individuals has involved. The case of the music industry is instructive here (Kernfeld, 2011).

${ }^{11}$ It should be noted here that the word pirate by itself has a strong moral connotation which is deliberately employed (Seville 2010).
} 
work is used. How 'substantial' it has to be is difficult to assess and strongly contextdependant. Recorded game play in particular can be long and is often live streamed for hours at a time. However, even short extracts can be infringing because the uploaded materials are usually core scenes which carry the storyline or character development (Kato, 2013, 184$185)$.

A key difference to EU and US law needs to be noted. The Japanese transmission right focuses on the upload: the infringer is whoever makes the work transmittable by introducing it to the network. If and who can access the work has no bearing (Kato, 2013, 4144). Downloading material, on the other hand, is covered by the private copying exemption and therefore not infringement (Yamada, 2016, 59), except in the case of music and film works (Japanese Copyright Act, article 119(3)). ${ }^{12}$ In other words, for an individual user uploading materials is infringing behaviour but downloading it is only infringing in the case of film works and music.

A second category of copyright infringement are the unauthorised translations made by fans for fans: rather than waiting for an official release of content, fans translate the material themselves and then share it with other fans. Fan translations exist for all three types of media but are most common for Anime and Manga. Just like the illegal up- and downloading of Japanese-language materials, fan translations are distributed in much the same way: specific homepages, YouTube and torrents.

Fan translations are clearly infringing both in terms of making the translation and their distribution. Under article 27, making derivative works is subject to copyright law and this explicitly includes translations (Japanese Copyright Act, article 27). Furthermore, any

\footnotetext{
${ }^{12}$ This is the result of industry lobbying when the law was changed to account for the harmful impact of illegal downloads. Illegal downloading at the time was not perceived as relevant for other types of media (Yamada, 2016, pp. 59-90). The punishments here are exceptionally strong: 2 years in prison, 2,000,000¥ or both. For a detailed description of item pricing and the attractiveness of copyright infringement, see Schroff (2019).
} 
use of a derivative work in a copyright-relevant way (here the digital distribution) requires the right holder's consent (Japanese Copyright Act, article 28). Without these permissions, fan translations in addition also breach the reproduction and transmission right of the underlying work (Japanese Copyright Act, article 21 and 23). At the same time, there are no applicable exemptions in the law as for example the private use exemption does not permit the transmission or even sharing of works beyond a very narrow circle of friends (Japanese Copyright Act, article 30).

The third piracy type are original fan works, such as Doujinshi (fan comics), art work, fan videos and fan fiction. All of these use copyright-relevant components of existing works, especially the characters, for their own works. For example, Doujinshi and fanfiction take famous characters and settings, then develop them into different story lines. Fan videos re-use existing video material from an Anime or video game and assemble it in another order, including favourite scenes, tracing a character's development, or to fit a particular song. These fan works are commonly distributed via specialist pages, fan community message boards but also large platforms such as YouTube and NikoNiko. Doujinshi in particular are also sold commercially at conventions, specialist Anime/ Manga stores ${ }^{13}$ and online stores which sell worldwide (Schendl, 2016, 641). As Mehra (2002, 165) points out, the number of events, the crowds it attracts, the income generated, the involvement of commercial firms, and the large market for manuals are all evidence for the commercial nature of the Doujinshi scene.

Legally speaking, Doujinshi and other fan-created works are directly comparable to the fan translations even though the use is more creative in its own right. Characters are protected by copyright law as artistic works under article 10(1)(iv), especially if they exist in

\footnotetext{
${ }^{13}$ Mandarake, a manga and anime chain, for example has a whole floor devoted to Doujinshi in its Akihabara store.
} 
a recognisable form such as an image (K.K. Matsudera, 1997). This applies to all of the media under discussion here: Manga, Anime and video game characters are all clearly identifiable and recognisable. As a result, fan works breach the reproduction right in respect of the characters and in some circumstances also the story line of the original work which is protected from unauthorised reproduction under article 21. In addition, fan works are derivative works under article 27 and article 28 just like fan translations are. Finally, when fan works use established characters and then write their own storylines, they are also breaching the right to integrity under article 20 (Mehra, 2002, 173).

There are no applicable exemptions under the Japanese law. Japan relies on a closed list of exemptions which means that any exempted activity has to match the purposes and requirements of the listed exemptions. If it does not, the behaviour has to be considered infringing. In the context of fan works, especially Doujinshi, the most common cited exemption is the quotation or criticism provisions under article 32(1). However, neither one applies because both rules require that the active use of the quoted/ criticised work for that stated purpose (Mehra, 2002, 176-177). Similarly, assertions that the parody exemption may apply (Foster, 2013, 315) has been negated because the fan work does not actually criticise the underlying work $(\mathrm{He}, 2014,1018)$. Fan works also do not fall under private use because the distribution is wider than the limited circle (Arai and Kinukawa, 2014, 132). In other words, the law does not allow the re-use of characters to tell an original story.

\section{Managing infringing behaviour by meeting customer demand}

The main approach to addressing unauthorised uses of copyright protected works described above in the digital environment is not enforcing copyright but preventing it in the first place. The action taken depends on the context and especially differs between the export and domestic market. 
Turning to the domestic market, right holders first seek to actively meet the demand for content: the media examined here can be conveniently accessed cheaply and legally in Japan. Manga, Anime and video games can be easily bought online and downloaded at any time through online stores. In addition, access to Manga and Anime in particular is cheap. Manga cost about $1.50 \$$ per volume and Anime streaming services such as Amazon Prime and the different broadcaster portals offer access to a wide range of material for $\sim 1 \$$ per episode in addition to bundles. Most notably, this is significantly cheaper than DVDs or Bluerays $(\sim 20 \$)$. The only media product examined here where this does not apply are video games. Video games are generally more expensive $(\sim 50-60 \$)$ and the prices are the same for digital and analogue products.

The second part of the business model is to limit "undesirable" user behaviour in the context of the infringing potential digital access can have. The key characteristic of all the digital distribution channels examined here is that the content can only be accessed via the software the right holder provides. This includes Anime streaming sites, reading apps provided by the publishers or Amazon and the game engines and consoles for video games. By controlling the software, the right holders provide what is essentially a closed environment. The benefits of this for the right holder have been described extensively in the Western context by Perzanowski and Schultz (2016): control over user behaviour. Depending on the specific features the right holder offers, users are steered towards "desirable" behaviour, such as watching the Anime; but actively discouraged from others, for example sharing the product with a friend. Most notably, what is available to the user and what is not does not follow copyright principles. For example, although Japanese copyright law allows users to make private copies, the environments in which products are presented do not offer 
this option ${ }^{14}$ and items cannot be shared with friends in the same way copyright law permits and indeed is common for analogue products. ${ }^{15}$ Users have little choice in this because it requires significant effort and some technical skill to extract works from these closed environments.

Copyright's role in this context is a backup function and a facilitator. Under Japanese (and indeed US or European law), tampering with the copying controls and other digital rights management (DRM) mechanisms is copyright infringement in its own right (Japanese Copyright Act 113(3)). This means that extracting content is not only difficult but also illegal under copyright law. At the same time, many exemptions such as the private copying provisions do not apply to this provision (Japanese Copyright Act, article 30(1)(ii) and 113(3)). For example, Anime and Manga related video games are console- specific and not meant for the computer. Most consoles, such as the Sony PlayStation and the different Nintendo consoles include chips which detect non- authorised copies; stopping the console from playing them. ${ }^{16}$ Private copies can therefore not be used. As a result, the line between desired and undesirable behaviour is set by the right holders, backed up by copyright law but not based on its principles.

An adapted version of this approach also characterises the export market, in particular the contents industry's response to fan translations. ${ }^{17}$ Fan translations are driven by the (perceived) shortcomings in how products are licensed in other countries. First, there is a significant time delay between the Japanese and its international releases which is filled by the fans. In response, there is an increasingly strong drive to have simulcasting for Anime and

\footnotetext{
${ }^{14}$ Examples here include all kinds of downloadable products, including manga cell phone apps, the Kindle environment but it also affects downloads from the iTunes store. This phenomenon has been analysed in the Western context as well (Perzanowski and Schultz, 2016)

${ }^{15}$ Especially Manga have a long tradition of being shared with friends and re-sold at second hand book chains such as BookOff. For a detailed explanation and the role of copyright within it, see Schroff (2019).

${ }^{16}$ For a broader view on the technical difficulties involved in copying video games, see (Yamada, 2016, 60).

17 This is only part of the explanation, see below for tolerating infringement.
} 
simultaneous publishing for Manga (VIPO, 2018). These strategies explicitly aim at the time gap by providing immediate legal access, reducing the need for the fan to use fan translations while at the same time making it nearly impossible for fan translation groups to be faster than the official release. Since time is of the essence, most of these distributions are digital and rely on the same closed environments approach. Secondly, fan translations have been triggered by fans' dissatisfaction with low- quality authorised translations (Muscar, 2006, 224) and the extensive adaption for the target market (He, 2014, 2017). Right holders have taken this criticism on board as the degree of adaptation has generally decreased especially if a series is not primarily aimed at children (VIPO, 2018). Translations now stay closer to the original, explaining foreign terms rather than resorting a rough equivalent translated version (Rampant, 2010, 221). Right holders have therefore addressed fan translations by meeting the fans' demands rather than targeting translators using copyright law.

However, significant gaps remain and with it, the translation communities continue to thrive. This includes the lack of suitable digital distribution channels such as cell phone Manga ${ }^{18}$ and most Manga and Anime are never released officially abroad (Lee, 2009, 1011; Schendl, 2016, 642). This is still the case but not necessarily of much concern to the right holder. Fan translations affect exports and if the foreign markets are not considered a target anyway, the cost of enforcement is essentially a waste of resources. As Brienza argues in the context of Manga, midlist titles have lower profit margins and do not sell well enough for the publisher to attempt a simultaneous lay-down and bear the additional costs that this entails (Brienza, 2014, 392). As a result, fan translations actually trigger a kind of piracy cycle: fan translations exist because there is no official release of the series but at the same time, they can be an obstacle to licensing a series in the first place. This means that while right holders

\footnotetext{
${ }^{18}$ Issues range from zooming, presenting double-page art work as well as the lack of colour and low resolution of the Kindle.
} 
have actively sought to limit the scope of infringement by providing legal, timely access to high quality products abroad, their efforts remain limited to what is seen as economically viable and feasible.

Overall, right holders aim to provide convenient and cheap access to content by using closed environments, supporting "desired" behaviour while at the same time making "undesirable" behaviour as difficult as reasonable possible. Copyright sanctions here enforce the system indirectly by raising the cost of piracy as breaching the technical measures is not only skill and resource intensive but can prosecuted as copyright infringement. However, it does not draw on the most potent sanctions available, such as the illegal downloading provisions, despite the immense political capital that spent on this. In addition, it does not eliminate piracy as whole as the previous section has shown. This now raises the question to how right holders react to the different kinds of infringement and why.

\section{Addressing copyright infringement}

Full enforcement: market harm and replaced sales

Based on the interviews, the first priority for right holders is to target infringement that replaces sales. Right holders explained these efforts with the classical free rider theory (right holder interviews). Following this logic, every illegal download or stream represents a direct loss of sales and therefore income because the product is available for free: the rational user would opt for these if he is only concerned about money. ${ }^{19}$ Unless he has moral considerations to pay the additional cost of accessing the work, for example a wish to support the artist, there is no overwhelming reason for him to pay if he can get the content for free. In

\footnotetext{
${ }^{19}$ It should be noted that not every download is a lost sale. See for example, see Oberholzer and Strump (2007) and Perzanowski and Schultz (2016).
} 
other words, if the unauthorised use acts as a market substitute, then the right holder loses his ability to sell his works and therefore suffers direct economic harm.

This explains why illegal uploads and streaming of whole episodes are actively targeted by right holders (right holder interviews; legal practitioner interviews; ACCS, 2018). Systematic searches on large video- sharing platforms also show that works are removed automatically and quickly. None of the popular Animes for example have any episodes on the Japanese YouTube and if they do appear, they are removed within 2-3 days. ${ }^{20}$

Indeed, any gaps of enforcement are attributed by the right holders to technological difficulties rather than tolerance on their part. The automated enforcement systems are not as efficient with extracts as they are with full- length material. Full episodes can evade them if their running time is changed, for example extending 20 min episodes to 30 min, or by adding an image-overlay such as transparent bubbles. ${ }^{21}$ The only other option would be take- down notices but these require significant resources as the material has to be identified and takendown manually. This is only viable for the most popular series or largescale infringers (legal practitioner interviews 4, 7, 8; right holder interviews 3-7, 9; ACCS, 2018).

It should be noted here that there is very little evidence that the criminal sanctions for downloading materials by individuals which the right holders lobbied hard for are being used. This implies that the political capital was spent on a provision that has very little practical relevance to right holder considerations. This can at least be partially explained by other factors which mitigate against taking legal action as such. First, there is still a cultural reluctance to sue because it can affect business relations (Mehra, 2002, 181; Schodt, 2011,

\footnotetext{
${ }^{20}$ Observation of YouTube and NikoNiko search results between November 2017 and January 2018 for the 10 most popular Anime series.

${ }^{21}$ Observation of YouTube and NikoNiko search results between November 2017 and January 2018 for the 10 most popular Anime series.
} 
42). ${ }^{22}$ In part, companies do not want to be seen as aggressive by their business partners, especially if the potential rewards are limited (legal practitioner Interviews). In addition, litigation in Japan is less profitable than in the US because the level of compensation a right holder can receive is lower (legal practitioner interviews; Mehra, 2002, 161). However, it is not entirely clear if this reluctance is the result of right holder attitudes or the influence of legal practitioners on their clients. For example, some legal practitioners stated that they advise against legal action unless there are aggravating circumstances (legal practitioner interviews, especially 10 and 11).

In other words, right holders do not show any tolerance towards infringing behaviour that affects full works made available online. Gaps are the result of limited resources given the high cost of action in combination with comparatively low pay-outs and detrimental reputational effects, not tolerance as such. This attitude however does not extend to snippets or other partial works.

\section{Tolerating infringement: the power of marketing}

In difference to whole episodes, the uploading and streaming of partial works is largely tolerated based on two intrinsically linked arguments. First, snippets are less likely to replace sales because watching individual core scenes is not the same experience as watching the movie as a whole. This is essentially the same reasoning that explains why right holders seek to take down full episode uploads: direct market harm through replaced sales. Equally important is that snippets and extracts can work like trailers. By exposing potential customers to some material and showing its attractiveness, it can support future sales when these people buy the product (right holder interviews).

\footnotetext{
${ }^{22}$ This point was confirmed by several legal practitioners but they saw it as less practically relevant than the literature suggests.
} 
This twofold logic is most directly illustrated in the context of fan translations. In addition to providing fans with access to favourite series as discussed above, fan translators also aim to create a buzz about their favourite series in the hope that it may be licensed officially in their home country (Lee, 2009, 1016). This attitude is reflected in the community ethos: no distribution after the product is licensed; delete archives, and urge fans to buy the licensed version. Indeed, those not following the rules are considers pirates by fan translators themselves (Rampant, 2010, 227). In this sense, the fan translations do not replace the legitimate sales but incentivise it. Copyright infringement is only a necessary evil (Lee, 2009, 1016-1017). This explains why fan translations are tolerated: they are not a threat as long as they adhere to these rules (right holder interviews, 4, 5, 8). Having said this, right holders will enforce their rights if the fan translators deviate. Aggregator sites especially are targeted because they do not adhere to these rules and have a detrimental effect on sales and are defacto commercial (Lee, 2009; Brienza, 2016,146; ACCS, 2018). This point however did not feature significantly in the interviews, probably because it will be licensing subsidiaries in the affected jurisdictions that would take action (legal practitioner interview 13).

Considering video games, it becomes clear that this tolerance for marketing purposes can develop negative impacts on copyright legitimacy as such. Fans today expect to share their gameplay and companies feel they must meet this fan demand (fan interview 4; right holder interviews 1, 7,9). At the same time, the recorded game play acts as advertisement, perceived to incentivise future sales. As a result, most consoles today have the inbuilt capability to record and share gameplay online. However, the way it is done is actually an issue in itself. User agreements sometimes include licenses for the user to upload the material. However, most users do not read the fine print (Perzanowski and Schultz, 2016) and are therefore often not aware that they have the permission to upload or stream anything. This means that right holders may accidentally facilitate infringing attitudes: by hiding the 
copyright relevance of the behaviour, the uninformed user perceives his activities as either not-copyright relevant or a private-copying kind of permitted use. Neither one is correct.

In practice therefore, right holders strongly differentiate between unauthorised uploading of partial and whole works. However, all of these activities are clearly infringing under copyright law and portrayed as such in the public discourse. As a result, any tolerance has to be considered an example of selective non-enforcement of copyright and in the case of recorded gameplay, at least indirectly facilitating infringing attitudes among consumers.

\section{The power of fans and the value of brands}

Market harm and promotional effects cannot explain the most striking example of tolerated infringement discussed here: Doujinshi which often fall under commercial copyright infringement. Despite this, there have only been very few isolated cases where fan works have been subject to copyright enforcement (He, 2012, 1014). Instead, Japanese right holders are largely tolerating them. For example, many publishers have their own booths at Doujinshi and fan events (Author observations; Matsui, 2016, 236) while other commercial entities also participate e.g. printing companies, art supply firms etc (Schodt, 2011, 38). In some cases, right holders go even further and actively support the scene. This includes buying fan works themselves (Schodt, 2011, 38; Peaslee, 2014, 226).

In the academic literature, the tolerance for Doujinshi has several overlapping explanations. First, Doujinshi are not considered a market harm. Most Doujinshi do not qualify as substitutes for the original (He, 2014, 1033) and the overall Doujinshi market remains small compared to the professional Manga market and therefore does not threaten the latter (Arai and Kinukawa, 2014, 133). Secondly, there are long established links between the professional Manga and Doujinshi market. Many Anime and Manga artists have started out in the Doujinshi market or are still active in it (He, 2014, 1033). In turn, these personal links and experiences translate into a personal attitude of not pursing these fans (Lee, 2013, 188). 
Thirdly, Manga's global success lies in its widespread fan-activities (Condry, 2013, 108) and popularity of content among Doujinshi artists is by itself a legitimate measure of success (Lee, 2013, 190). Finally, many Doujinshi artists also draw original Manga and the Doujinshi market is especially innovative in terms of styles and ideas. Tolerating the infringement produces a positive externality in the sense that publishers can foster innovation (Arai and Kinukawa, 2014, 133). This in turn can enhance future sales. As a result, publishers consider Doujinshi tolerance as an unspoken agreement that serves to promote the industry as a whole (Mehra, 2002, 184). The benefits simply outweigh the costs in terms of replaced sales.

However, none of these arguments emerged consistently in the interviews with right holders or legal practitioners. Instead, their perception was that Doujinshi were neither harmful nor particularly beneficial. Instead, they emphasised the reputational damage taking action against fans would entail (right holder interviews, legal practitioners interviews). Most notably, several interviewees brought up the same deterring example of a fan backlash: the 2000s campaign by RIAA in the US. ${ }^{23}$ This reasoning has been attributed in the literature as well. Lee for example argues that fan activities are not new and have simply migrated from the analogue to the digital domain. Starting to enforce their copyright now, especially if a company decides to go it alone, can alienate the fan base and therefore their customers (Lee, 2009, 1018-1019). This does not mean that right holders will never take action against fans. In the interviews, both right holders and legal practitioners emphasised that the actual focus of protection for them were not individual works but the brand, especially the way Manga, Anime and video games are linked by a set of characters and storylines (right holder interviews 3,4, 6; legal practitioner interviews 1, 11-14; Davies, 2016). As a result, there are mutually understood limits of what is acceptable: amateur artists, professional artists and

\footnotetext{
${ }^{23}$ For a description of the RIAA campaign and its failure, see Kernfeld (2013). Legal practitioners especially emphasised that their clients fear this kind of reaction.
} 
right holders all work within these limits (Lee, 2009, 1014 and 1022). Fan works will be subject to copyright enforcement if they are perceived to harm the market by affecting the value of the original (Arai and Kinukawa, 2014, 134).

In the interviews, it became clear that there are some differences in perception here. Right holders and legal practitioners clearly separated out a small number of activities they saw as problematic. Pornographic fan work is particularly liable to be subject to infringement action (legal practitioner interviews, especially 1, 7, 13; He, 2014, 1015). Similarly, if the fan work is very close to original and leads to confusion, then right holders are more likely to take action $(\mathrm{He}, 2014,1014)$. This situation seems to be rare because it was not raised in any of the interviews. Fans on the other hand were consciously aware of the infringing nature of their work, portraying the acceptable free space as narrow (fan interviews, 1-7). This is confirmed by the author's observations at Doujinshi events where she was often refused permission to take photographs on the basis that this would infringe the original's copyright. ${ }^{24}$ This clearly demonstrates a division in perception: while right holders conceptualise fan works in terms of their effect on the brand, fans understand the limits as tolerated copyright infringement. As a result, right holders see themselves as very tolerant of fan activities, e.g. only taking action when the fan work actually harms them, while the fan artists feel that they a treading a fine line, being constantly threatened by copyright infringement claims.

\footnotetext{
${ }^{24}$ Interestingly, this was especially pronounced at the largest Doujinshi convention, the Comiket, while smaller, informal events raised this issue only very infrequently.
} 


\section{Conclusion}

This article has analysed how Japanese right holders address copyright infringement in the digital domain, focusing on when and how Japanese copyright holders exercise their rights in the context of the Anime, Manga and video game sectors. It has demonstrated that the decision to use copyright law is based on a combination of non- copyright factors. First, right holders seek to provide convenient and affordable access to works in a manner that limits the options for consumers to deviate from how they consider consumers should interact with their products. This serves to limit infringing uses but does not eliminate them.

When piracy occurs, right holders assess their options based on a cost- benefit analysis. The greater and the more directly their business models are affected by replaced sales and damage to the brand, the more likely the right holders are to enforce their rights. At the same time, right holders also take into account that some infringing uses can have an advertising or similarly beneficial effects on their products and encourage or at least tolerate those. This tendency is even stronger if copyright enforcement is likely to alienate fans or business partners. In this sense, right holders weigh the benefits and costs of enforcement, leading to a strategy of selective enforcement where only some infringers are targeted while others are tolerated or even encouraged. Copyright law and its principles only play a minor role in that calculation. Instead, right holders shape user behaviour with closed environments and affordable access but the specific features are not determined by copyright law. The lack of private copying facilities as part of the closed environments in which customers access digital works is just one example. Copyright law, its enforcement and discourse have become divorced from industry practice. The majority of its provisions, even those that result from extensive industry lobbying, are not enforced, either explicitly or implicitly.

There are major similarities between Japan, the EU and the US. First, the reliance on closed environments based on technological measures is clearly visible in all three 
jurisdictions, even though some distribution channels such as cell-phone Manga are Japanspecific at this point in time. Secondly, Japanese copyright law is comparable to the ones common in Europe and the US and indeed may be even more restrictive. This article is based on a single case study and therefore only limited generalisation can be drawn but some key points are worth further consideration.

The first aspect is that right holders are already not using the full range of options copyright provides them with. Given public opposition reforming copyright entails, it seems clear that spending their political capital on stricter copyright is not the most efficient way forward for most right holders. Secondly, the balance of power has shifted significantly towards the right holders and away from users. The circumvention of copyright exemptions in particular reduces the scope for using digital materials for established exempt uses such as teaching or private copying. From a copyright point of view, this development needs to be closely monitored because the balance of power is one of major factors legitimising copyright in the first place. It also bears the potential for a major consumer backlash if copyright is seen as inherently unfair.

Thirdly, copyright law as it applies to digital works has to be comprehensively reassessed. The notions of market harm and brand value are clearly key to understanding how copyright works in the digital domain. These principles are not congruent with copyright law which conceptualises copyright interests as right holders against users. Instead, market harm and brand value allow for a myriad of context-dependant assessments, leading to gaps in the form of selective enforcement. This inconsistency in turn can affect the legitimacy of the law as a whole because it is not clear to infringer why he is targeted while others are not. Indeed, developments in Europe where stricter copyright protection is opposed by the same firms it is 
designed to benefit shows that a simplistic view of copyright cannot and should not be maintained..$^{25}$

In conclusion, the existing copyright provisions need to be re-assed for their effect and relevance. A simplistic view on right holder interests, users and infringement has led to inconsistencies which are now very apparent in the form of selective copyright enforcement and are undermining the system as a whole. Instead, the discourse needs to shift from high levels of protection towards effective protection. This may potentially require a division between copyright for analogue and digital works, especially in relation to the right holderuser interface. At least, potentially obsolete provisions need to be re-assed and maybe removed as part of a copyright streamlining reform and existing exemptions need to be consistently adapted to the digital reality.

${ }^{25}$ See the discussions for the new EU copyright directive. 


\section{References}

Arai, Hisamitsu. 2005. "Intellectual Property Strategy in Japan. International Journal of Intellectual Property Law”, Economy and Management 1: 5-12.

Arai, Yasuhiro and Shinya Kinukawa. 2014. "Copyright Infringement as User Innovation”. Journal of Cultural Economics 38: 131- 144.

Association for Computer Software Copyright Infringement (ACCS) (一般社団法人コンピュー タソフトウェア著作権協会), “Copyright Infringement Incidents” (著作権法侵害事件).

Accessed October 16 2018. http://www2.accsjp.or.jp/criminal/.

Braithwaite, John and Peter Drahos. 2000. Global Business Regulation. Cambridge:

Cambridge University Press.

Brienza, Casey. 2014. "Did Manga Conquer America? Implications for the Cultural Policy of 'Cool Japan'”. International Journal of Cultural Policy 20(4): 383-398.

Brienza, Casey. 2016. Manga in America. London: Bloomsbury.

Cabinet Office- Government of Japan. 2018. “Cool Japan Strategy”. Accessed October 16 2018. http://www.cao.go.jp/cool_japan/english/index-e.html.

Condry, Ian. 2013. The Soul of Anime: Collaborative Creativity and Japan's Media Success Story. Mountain View: Duke University Press.

Courmandis, Nadine. 2009. "The Criminalisation of Copyright Infringement in Japan and What This Tells Us about Japan and the Japanese”, Asia Pacific Law Review 17: 167- 184. Doi: https://doi.org/10.1080/10192557.2009.11788198

Davies, Gill and Richard Balkwill. 2011. The Professionals' Guide to Publishing- A Practical Introduction to Working in the Publishing Industry. London: Kogan Page.

EU. 2001. "Directive 2001/29/EC of the European Parliament and of the Council of 22 May 2001 on the harmonisation of certain aspects of copyright and related rights in the information society". Official Journal L 167 of 22 June 2001: 0010 - 0019.

EU. 2004. "Directive 2004/48/EC of the European Parliament and of the Council Of 29 April 2004 on the Enforcement of Intellectual Property Rights." Official Journal of the European Union L 157 of 30 April 2004: 0033- 0044.

Foster, Mariko. 2013. "Parody's Precarious Place: The Need to Legally Recognise Parody as Japan's Cultural Property”, Seton Hall Journal of Sports and Entertainment Law 23(2): 313344.

Goldstein, Paul. 2010. International Copyright: Principles, Law and Practice. Oxford: Oxford University Press.

He, Tianxiang. 2014. "What Can We Learn from Japanese Anime Industries? The Differences Between Domestic and Overseas Copyright Protection Strategies Towards Fan Activities". American Journal of Comparative Law 62: 1009- 1042. 
Intellectual Property Strategy Headquarters. "Intellectual Property Strategy Program 2017". Accessed October 152018.

https://www.kantei.go.jp/jp/singi/titeki2/kettei/chizaikeikaku2017_gaiyou_e.pdf.

Kato, Moriyuki. 2013. Copyright Law: Article by Article Analysis (著作権法逐条講義). $6^{\text {th }}$ ed. Tokyo: Copyright Information Center.

Kawashima, Nobuko. 2010. "The rise of 'user creativity'- Web 2.0 and a challenge for copyright law and cultural policy”, International Journal of Cultural Policy 16(3): 337-353.

Kernfeld, Barry. 2011. Pop Song Piracy: Disobedient Music Distribution since 1929. London: University of Chicago Press.

K.K. Matsudera v. King Features Syndicate, Inc., Saik6 Saibansho [Sup. Ct.] Jul. 17, 1997, 1992 (o) No. 1443, translated at http://www.softic.or.jp/en/cases/popeye.html (Japan).

Yasuto Komada, Hisao Shiomi and Takakuni Yamane. 2016. Intellectual Property Law II: Copyright Law (知的財産法 II: 著作権法). Tokyo: Yuhikaku.

Landes, William and Richard Posner. 2003. The Structure of Intellectual Property. Cambridge, MA Harvard University Press.

Lee, Hye- Kyung. 2010. "Between Fan Culture and Copyright Infringement: Manga Scanlation". Media, Culture \& Society 31(6): 1011- 1022.

Lee, Tiffany. 2013. "Fan Activities from P2P File Sharing to Fansubs and Fan Fiction: Motivations, Policy Concerns, and Recommendations". Texas Review of Entertainment and Sports Law 14(2): 181-198.

Leonard, Sean. 2005. "Progress against the law: Anime and fandom, with the key to the globalization of culture", International Journal of Cultural Studies 8(3): 281-305.

Lessig, Lawrence. 2004. Free Culture: The Nature and Feature of Creativity. London: Penguin Books.

Matsui, Shigenori. 2016. "Does it have to be a Copyright Infringement?: Live Game Streaming and Copyright”. Texas Intellectual Property Law Journal 24: 215- 244.

Mehra, Salil. 2002. "Copyright and Comics in Japan: Does Law Explain Why All the Cartoons my Kid Watches are Japanese Imports?”. Japan Rutgers Law Review 55: 155- 204.

Muscar, Jaime. 2006. "A Winner is Who? Fair Use and the Online Distribution of Manga and Video Game Fan Translations", Vanderbilt Journal of Entertainment and Technology Law 9: 223-254.

Oberholzer- Gee, Felix and Koleman Strump. 2007. "The Effect of File-Sharing on Record Sales: An Empirical Analysis”. Journal of Political Economy 115(1): 1-42.

Peaslee, Samantha. 2014. "Is There a Place for Us?: Protecting Fan Fiction in the United States and Japan”. Denver Journal of International Law and Policy 43: 199- 277.

Perzanowski, Aaron and Jason Schultz. 2016. The End of Private Ownership: Personal Property in the Digital Economy. London: MIT Press. 
Rampant, James. 2010. "The Manga Polysystem: What Fans Want, Fans Get”. In Manga: An Anthology of Global and Cultural Perspectives edited by Toni Johnson- Woods, 221- 233. London: Continuum.

Schendl, Emily. 2016. "Japanese Anime and Manga Copyright Reform”. Washington University Global Studies Law Review 15(4): 630-652.

Schodt, Frederik. 2011. Dreamland Japan: Writings on Modern Manga. Berkeley: Stone Bridge Press.

Schroff, Simone. 2019. "An alternative universe? Authors as copyright owners- the case of the Japanese Manga Industry". Creative Industries Journal.

DOI: $10.1080 / 17510694.2018 .1563420$

Seville, Catherine. 2010. "Nineteenth- Century Anglo- US Copyright Relations: the Language of Piracy Versus the Moral High Ground". In Copyright and Piracy: An Interdisciplinary Critique edited by Lionel Bently, Jennifer Davis, Jane Ginsburg, 19- 43. Cambridge: Cambridge University Press.

Yamada, Shoji. 2012. Why has Japanese copyright become so strict? (日本の著作権はなぜこ んなに厳しいのか). Tokyo: Jinbunshoin.

Yamada, Shoji. 2016. Why has Japanese copyright become extremely strict? (日本の著作権 はなぜもっと厳しくなるのか). Tokyo: Jinbunshoin.

VIPO. 2018. "Recent Developments in the Online Market", In VIPO Seminar for Industry Professionals Online and Real: the Rules of the North American Anime Marketplace Place, Tokyo Big Sight March 232018. 